\title{
Propensity to Pay Dividends: Evidence from US Banking Sector
}

\author{
Jamal Al-Khasawneh ${ }^{1}$, Mohammad Shariff ${ }^{1} \&$ Khalid Al-Zubi ${ }^{2}$ \\ ${ }^{1}$ Department of Economics and Finance, College of Business Administration, Gulf University for Science and \\ Technology (GUST), Hawally, Kuwait \\ 2 Department of Finance and Banking, Faculty of Economics and Administrative Sciences, The Hashemite \\ University, Zarqa, Jordan \\ Correspondence: Jamal Al-Khasawneh, Department of Economics and Finance, College of Business \\ Administration, Gulf University for Science and Technology (GUST), Hawally, Kuwait. Tel: 965-2530-7440. \\ E-mail: Alkhasawneh.j@gust.edu
}

Received: June 12, 2012

doi:10.5539/ijef.v4n9p130
Accepted: July 23, $2012 \quad$ Online Published: September 1, 2012

URL: http://dx.doi.org/10.5539/ijef.v4n9p130

\begin{abstract}
Using Fama and French's (2001) methodology, this paper attempts to shed light on dividend policy and propensity to pay cash dividends implemented by U.S. commercial banks as a possible alternative choice for dividend-seeking investors. The results show that most banks pay dividends at increasing rates, more banks have started paying dividends, while a few have stopped paying dividends. The findings also indicate that the main explanatory variables in predicting cash dividends are: the total assets, return on equity, and equity to liability ratio.
\end{abstract}

Keywords: dividends, dividend policy, propensity to pay, banking/financial institutions

\section{Introduction}

Since the publication of the seminal paper on the irrelevance of dividend policy by Modigliani and Miller (1961), the dividend policy of firms has been one of the most important classical research topics in the finance literature. Fama and French (2001) provided empirical evidence that the relative number of dividend-paying firms has been decreasing over the last few decades. This is in part due to the changing characteristics of publicly traded firms. Start-up firms with low profitability and strong growth opportunities have developed a tendency to avoid initiating dividend payments. Regardless of this changing characteristic, a tendency has also been found for firms to be less likely to pay dividends. DeAngelo, DeAngelo, and Skinner (2004) stated that the evidence of decline in the number of dividend payers is confined to industrial firms and is not applicable to financial/utility firms. They also show that the number of dividend payers from financial/utility (industrial) firms has increased (declined) by $9.5 \%(58.9 \%)$ and that the banking industry accounts for $11.20 \%$ of the total market capitalization of all dividend-paying firms, and the dividends paid by them account for $14.64 \%$ of the total dividends paid by all public firms. Acharya, Gujral, and Shin (2011) have pointed out that banks continued to pay large dividends to their stockholders even after the 2008 economic crisis, "despite expecting large credit losses, breaching the principle of priority of debt over equity. This type of behavior can lead to default, and should therefore be avoided by banks".

Empirical evidence indicates that the dividend policy for banks is quite crucial. It signals quality in a banking environment that is best characterized by significant information asymmetry (Miller and Rock, 1985; Bessler and Nohel, 1996; 2000; Boldin and Leggett, 1995; Slovin, Sushka and Polonchek, 1999; Cornett, Fayman, Marcus, and Tehranian, 2011). Onali (2012) discusses the multidimensional aspect of the asymmetric information problems faced by banks and bank customers, shareholders, and examiners. This problem is an important aspect in hypothesizing that banks are different. Banks' shareholders usually expect regular dividends from these financial institutions as these institutions are perceived to be highly liquid. Frequent announcements of stable or growing dividends may therefore be utilized by banks as a means for providing positive information about the bank's solvency to all stakeholders. Hence, dividends provide some positive information about the bank's current success and about the future viability of the bank and vice versa.

Despite the extended literature on the overall issue of dividend policy, most studies exclude regulated firms from their analyses. High financial leverage and tight financial sector regulation implied that financial institutions are 
regulated and hence excluded from the sample in most of dividend policy studies (Lintner, 1956; Rozeff, 1982; Brennam and Thakor, 1990; Alli, Khan, and Ramirez, 1993; Heineberg and Procianoy, Fama and French 2001; 2000; Fenn and Liang, 2001; Grullon and Michaely, 2002).

However, there are very few studies about dividend policy in the banking industry (Casey and Dickens, 2000; Baker, Veit and Powell, 2001; Raghavan, 2005, Nnadi and Akpomi, 2005; Bodla, Pal, and Sura, 2007; Caprio, Laeven, and Levine, 2007). Some other studies had jointly examined the dividends policy of financial and nonfinancial institutions. Dempsey, Laber, and Rozeff, (1993); and Anderson, Mesak, Dickens (1999), Baker, Dutta, and Saadi (2008) support the industry-related dividend effect while Baker et al., (2001); and Frankfurter, Wood, and Wansley (2003) did not find any supporting evidence for the effect.

We believe that the dividends policy of banking sector deserve to be studied in depth for several reasons. First, the large size and the growing dividends paid by banks (DeAngelo et al. (2004), and Acharya et al. (2011)). Second, and according to Baker et al., (2008), the critical role financial firms habitually play in capital markets given their large market capitalization ratios in all financial markets all over the globe. Third, because of what Slovin et al. (1999) refers to as "contagion and comparative effect" of dividends paying banks where they examined the effect of the event of dividend paying at one bank generates externalities for the banking industry. We argue that the contagion effect of dividends paying large banks may have an effect on dividend payment behavior of non-financial institutions. Finally, and given the large number of banks' stakeholders than any other institution, banks may have stronger incentives to send reliable signals through dividend payouts about future profitability. Failing to do so could lead to losing depositors' confidence in banks, which could generate widespread bank runs (DeAngelo, DeAngelo, and Skinner (2000), and Baker et al., (2008)).

The main objective of this paper is to determine underlying variables used by U.S. banks to formulate dividend policy. For achieving the objective we are employing the methodology used by Fama and French (2001). To compare the results of this paper with Fama and French's results, the time period used for analysis in this paper is 1993-2000; which is the same as the latest study of Fama and French (2001).

\section{Previous Research}

Given the real scarcity of literature directly related to this topic, we use the literature that is relevant to the research question that comes from other related research areas of corporate finance and other regulated institutions.

Smith (1986) and Moyer et al (1992) examined the regulatory effect on dividend policy. Their results show that regulated firms use dividends as a means of subjecting the utility and the regulatory rate commission to market discipline. Dividend policies adopted by these firms are determined as a response to changes in policies adopted by regulatory commissions.

Akhigbe, Borde, and Madura (1993) measure the effect on common stock prices in response to dividend increases for both insurance firms and financial institutions and compare the effects to unregulated firms. They find that the stock prices of insurance firms react positively to increases in dividends over a four-day interval surrounding the announcement. Their results show that the market reaction for each subsample of Insurance Corporation is greater than the market reaction for financial institutions. Their results support that the market reaction is mostly determined by industry-related, rather than firm specific, variables.

Boldin et al (1995) found that there is a positive relationship between banks' dividend per share and banks quality rating, and a negative relationship between the dividend pay-out ratio and banks' quality rating, concluding that a bank's dividend policy yields information about the bank's quality.

Collins, Saxena, and Wansley (1996) compared the dividend pay-out patterns of regulated firms with those of unregulated firms. Their findings don't support that the financial regulators' role is one of agency cost-reduction for equity holders. Utilities, on the other hand, are different. They alter their dividend pay-out in response to changes in insider holdings. Moreover, for a given change in insider holdings, this policy change is more significant than the change for unregulated firms.

Slovin et al. (1999) examined excess returns to both announcing and rival banks. The results indicate that dividend reductions generate negative common stock returns for all announcing banks, and significant reduction in preferred stock prices of announcing banks, even though there are no concomitant changes in preferred stock dividends. Fama and French (2001) argue that firms with high profitability, good investment opportunities, and larger size tend to pay more than other firms. The three characteristics considered by Fama and French match the characteristics of banks, which are mostly large in size, highly profitable, have better investment opportunity sets, and are highly liquid. Baker et al., (2008) examine the perceptions of managers of Canadian firms listed on the 
Toronto Stock Exchange to determine whether views differ when partitioned into financial and non-financial firms. Their results suggest the existence of industry effects where the perceptions of managers from financial versus non-financial firms differ on the importance of various factors influencing the dividend policy of their firms.

Cornett et al., (2011) document a positive relationship between a bank's performance (in terms of profitability, capital adequacy, asset quality, operating efficiency, liquidity and growth) and dividends' initiation and between dividends' initiation and both takeover likelihood and merger premium, a conclusion that supports the signaling role of dividends. In their attempt to analyze the contagion effects of dividends reductions in the US banks.Onali (2012) found that banks that are close to depleting their capital (with low capital to total assets ratio) pay more dividends to their shareholders, arguing that dividends are used to shift risk from banks' owners to taxpayers. These findings are fully consistent with those of Acharya et al. (2011). Akhigbe and Whyte (2012) investigate the link between payouts and stock incentives among financial institutions with varying degree of regulation across depositories, insurers, and securities firms. Their findings show that managerial stock ownership is inversely related to dividend payouts across the institutions showing no evidence that the relationship occurs because of regulation since all institutions, regardless of the degree of regulation, exhibit the same inverse relationship between dividend payouts and management stock ownership. Their results support Collins et al., (1996).

\section{Data and Methodology}

The data of this study consists of 759 commercial banks, drawn from Bankscope for the period 1993-2000. We began with 1993, which is the earliest possible data available from Bankscope, and we ended with 2000 to prevent any regulation/deregulation acts. Another reason to use data from 1993-2000 is to make the results comparable with Fama and French (2001) results. However, it is worth mentioning that the initial sample consisted of 1425 banks, of which several observations were dropped due to incomplete information on all the variables chosen in this study. The banks studied in this paper did not go into merger activities or perform any act that might cause structural changes. Table 1 shows the descriptive statistics of the sample. The Table shows an increasing trend for pay-out ratio and an increasing trend in percentage of the payers. In 1993, the pay-out ratio was $38 \%$ and became $55 \%$ by 2000 . The percentage of payers also increased from $66 \%$ in 1993 to about $80 \%$ in 2000 .

\section{Model and Variables Definition}

Using Fama and French's (2001) logit model framework, and by adopting the same procedures to quantify the propensity for paying dividends, we built the following multivariate logit model, as shown in Equation (1).

$$
\begin{gathered}
\operatorname{Dum}(\text { Div })=\alpha_{0}+\alpha_{1}(\text { LOGTA })+\alpha_{2}(R O A)+\alpha_{3}(R O E)+\alpha_{4}(\text { LOANTA }) \\
+\alpha_{5}(\text { EQUITYTA })+\alpha_{6}(E Q U I T Y L I)+\varepsilon_{I}
\end{gathered}
$$

As mentioned above, we tried to keep our variable as close as possible to the variables used by Fama and French (2001). To account for the size effect, we chose the log of total assets (LOGTA). We expected that the larger the bank size, the more likely it would be to pay dividends. The profitability is represented by two variables: return on assets (ROA), and return on equity (ROE). Again, we expected the higher the profitability the higher the pay-out ratio. The investment opportunity here is represented by the loan to total assets ratio (LOANTA); we hypothesized that the higher the assets' utilization through loans, the higher the pay-out will be. We further added the safety variable to account for the effect of safety considerations in the banking sector; two ratios were chosen: equity to total assets (EQUITYTA), and equity to total liabilities (EQUITYLI). Our expectations about these variables were mixed. On one hand, we believed that manager would want to compensate the shareholders if they participated more in financing the banks' activities, but on the other, if the manager wanted to keep the coverage ratio high, then we expected that he would retain a high portion of net income and be very reluctant to pay cash dividends. To examine the characteristics of dividends payers, we used logit regression, which was performed firstly for the whole period (1993-2000), and then on annual bases to test how the coefficients changed over time. Furthermore, we subsampled our overall sample according to their cash dividend-paying trends; here we had four different dividend-paying groups: banks which kept paying dividends for the whole period, banks which stopped paying, banks which paid more than the net income of the spot year, and banks which had already started paying.

\section{Empirical Results}

Table 1 shows the descriptive statistics of the data set analyzed in this paper. Table 2 presents the logit regression results for the whole sample of banks for the period 1993-2000. The results show a significant intercept when 
using either the whole sample or another time subsample, which indicates the stickiness of the dividends policy adopted by U.S. banks. The findings also show a positive relationship with total assets, return on equity, and equity to total assets, and a negative relationship with equity to total assets. Accordingly, it can be concluded that large banks with high equity tend to pay more dividends.

Table 1. Descriptive statistics of total assets, net income, dividends paid, and the percentage dividends paid for each year (Millions US \$)

\begin{tabular}{lllllllll}
\hline Year & 1993 & 1994 & 1995 & 1996 & 1997 & 1998 & 1999 & 2000 \\
\hline Number of Observations & 778 & 871 & 941 & 1064 & 1106 & 1142 & 1175 & 1181 \\
Total Assets (Tens of Billions) & 6.6558 & 6.7303 & 6.7975 & 6.9222 & 7.0246 & 7.1066 & 7.169 & 7.2216 \\
Average Net Income & 49116 & 54879.9 & 65472.4 & 98576.9 & 119792.5 & 139253.5 & 175626.8 & 188321.5 \\
Dividends Paid & 18756 & 23429.7 & 31486.1 & 54657.4 & 65081.9 & 73569.2 & 104573.5 & 103130.3 \\
Pay-out Ratio & 0.3819 & 0.4269 & 0.4809 & 0.5545 & 0.5433 & 0.5283 & 0.5954 & 0.5476 \\
Dividends./Assets & 0.0041 & 0.0044 & 0.005 & 0.0065 & 0.0061 & 0.0058 & 0.0071 & 0.0062 \\
Total Number of Banks & 757 & 846 & 913 & 1036 & 1069 & 1099 & 1139 & 1137 \\
Number of Dividend Payers & 501 & 608 & 664 & 789 & 827 & 853 & 910 & 907 \\
\% of Banks Paid Dividends & 66.18 & 71.87 & 72.73 & 76.16 & 77.36 & 77.62 & 79.89 & 79.77 \\
\hline
\end{tabular}

This table provides descriptive statistics of total assets, net income, dividends paid, and the percentage dividends paid for each year (Millions US \$)

For the safety ratios, we have two results. For EQUITYTA, we have a significant negative slope, which means the higher the equity the less the pay-out. This is a very interesting result because it tells us that managers do not care who finances their operations. The other result is related to the EQUITYLI ratio, which indicates a positive significant relationship between the dividends paid and the coverage ratio; the more the bank is covered, the more it will pay dividends. The other results reported in Table 2 show how the coefficients change over time. In general, the size, LOGTA, looks the most persistent variable in determining the pay-out policy. ROE is still significant for some periods. To make sure that we did not miss the effect of our selected variables on the future pay-out policy, we used logit again, but this time with the lagged dummy variable (namely year $\mathrm{t}-1$ ). The results are shown in Table 2. Table 2 confirms our results where LOGTA is still the most significant and persistent explanatory variable, followed by ROA, which still has some explanatory power. In Table 3, we utilized the logit estimates to make expectations about the next period pay-out ratio. Starting with 1994, we compared the actual pay-out ratio with the logit equation gained by using 1993 data. The results are represented in the last three columns of Table 3 which show that the actual dividends paid exceeded the expected dividends, reflecting the increasing propensity of banks to pay. This result is very interesting because Fama and French never reported such a result for the whole stage of their analysis. In general, when firms have a growing propensity to pay dividends (including banks), estimations tend to underestimate the future dividends, and vice versa.

Our next step was to repeat what we had already done, this time using several subsets. The reason for doing this was that we had already noticed that there were four distinctive trends in dividends policy. Table 4 and Table 5 report the results for the banks that had never cut paying dividends (which counts for about $70 \%$ of the total sample). The results are not much different from what those we reported in Table 2, in which this subsample counts for $70 \%$ or more of our entire sample. We still can see the significant positive effect of LOGTA.

Table 6 and Table 7 report the results of the banks that had stopped paying dividends for at least two years. Astonishingly, the size effect disappeared totally when using logit for the entire period. The only significant variable was LOANTA, which was still negative. Nothing changed in Table 7, except losing the significance of the LOANTA, The interesting part, if we assume that somebody will use these insignificant estimates, is that the expectations start exceeding the actual dividends' ratio. The explanation is that shareholders think that the bank is still paying when it has stopped doing so.

Table 8 and Table 9 reports the results for those banks which made at least two payments during the study period, exceeding their net income for those years. The results also fail to report any significant variables. We believe that the reason behind those results is the extraordinary nature of these payments. Most of the banks did this once or twice and no more. But what is unique in this case is the loss of the trend of the expectations. The last sample of our analysis is represented in Table 10 and Table 11. The subsample here consists of the banks that had already started paying dividends. This sample is the smallest in size (relative to the others). The result is the significant coefficient of LOGTA for the whole period, and from Table 10 we can see that most variables are 
significant except LOANTA; however, significant parameters do not exist for any single period. The last column of Table 11 shows the growing propensity to pay throughout the whole period during which the expectations never exceeded the actual dividends paid.

Table 2. Logit regression for all banks to discover the trend of dividend paying propensity for each year $\mathrm{t}$, for the period 1993-2000

\begin{tabular}{clllllll}
\hline PERIOD & C & LOGTA & ROA & ROE & LOANTA & EQUITYTA & EQUITYLI \\
\hline $1993-2000$ & -2.716 & 0.395 & 0.202 & 0.103 & -0.144 & -0.061 & 0.011 \\
& $(-11.39)^{* * *}$ & $(18.09)^{* * *}$ & $(1.85)^{*}$ & $(9.77)^{* * *}$ & -0.798 & $(-3.79)^{* * *}$ & $(2.37)^{* *}$ \\
1993.000 & -3.288 & 0.475 & 0.836 & 0.045 & -1.317 & 0.211 & -0.201 \\
& $(-3.76)^{* * *}$ & $(7.17)^{* * *}$ & 1.530 & 1.024 & $(-2.30)^{* *}$ & 1.354 & $(-1.96)^{* *}$ \\
1994.000 & -1.792 & 0.421 & 0.771 & 0.051 & -1.513 & -0.096 & 0.008 \\
& $(-2.34)^{* *}$ & $(6.36)^{* * *}$ & 1.426 & 1.184 & $(-2.77)^{* * *}$ & -1.316 & 0.371 \\
1995.000 & -1.914 & 0.391 & 0.447 & 0.074 & -0.939 & -0.080 & 0.007 \\
& $(-2.73)^{* * *}$ & $(6.16)^{* * *}$ & 1.112 & $(2.09)^{* *}$ & $(-1.82)^{*}$ & -1.484 & 0.320 \\
1996.000 & -2.008 & 0.320 & 1.820 & 0.009 & 0.713 & -0.246 & 0.070 \\
& $(-2.59)^{* * *}$ & $(4.96)^{* * *}$ & $(3.10)^{* * *}$ & 0.199 & 1.402 & $(-3.09)^{* * *}$ & $(2.58)^{* * *}$ \\
1997.000 & -1.954 & 0.365 & 0.094 & 0.096 & -0.010 & -0.132 & 0.039 \\
& $(-2.78)^{* * *}$ & $(5.84)^{* * *}$ & 0.291 & $(2.98)^{* * *}$ & -0.020 & $(-2.16)^{* *}$ & $(2.14)^{* *}$ \\
1998.000 & -2.959 & 0.373 & -0.692 & 0.206 & -0.385 & -0.039 & 0.024 \\
& $(-4.27)^{* * *}$ & $(5.88)^{* * *}$ & $(-2.32)^{* *}$ & $(6.32)^{* * *}$ & -0.733 & -0.817 & 1.359 \\
1999.000 & -3.206 & 0.377 & 0.293 & 0.116 & 0.372 & 0.005 & -0.034 \\
& $(-4.66)^{* * *}$ & $(5.94)^{* * *}$ & 1.044 & $(4.14)^{* * *}$ & 0.721 & 0.071 & -0.686 \\
2000.000 & -2.074 & 0.288 & 0.960 & 0.040 & 0.699 & -0.045 & -0.031 \\
& $(-2.88)^{* * *}$ & $(4.81)^{* * *}$ & $(2.35)^{* *}$ & 1.174 & 1.365 & -0.492 & -0.534 \\
\hline
\end{tabular}

The dependent variable is a dummy variable, 1 in year $t$ if the bank pays dividends, 0 otherwise. The explanatory variables are Log of Total Assets (LOGTA), Return on Assets (ROA), Return on Equity (ROE), Loan to Total Assets (LOAN_TA), Equity to Total Assets (EQUITYTA), and Equity to Total Liabilities (EQUITYLI). This table shows the means (across years) of the regression intercept (C) and coefficients of independent variables, and the significant t- statistics for the means are given in parentheses.

Table 3. Logit Regression to follow the trend of dividends paying propensity for each lagged year $\mathrm{t}-1$, for the period 1993-2000

\begin{tabular}{|c|c|c|c|c|c|c|c|c|c|c|}
\hline & $\mathrm{C}$ & LOGTA & ROA & ROE & LOAN_TA & EQUITYTA & EQUITYLI & ACTUAI & EXPECTED & EX-AC \\
\hline \multirow[t]{2}{*}{$94-2000$} & -1.615 & 0.374 & -0.042 & 0.053 & -0.337 & -0.075 & 0.022 & & & \\
\hline & $(-7.52)^{* * *}$ & $(18.29)^{* * *}$ & -0.714 & $(8.534)^{* * *}$ & $(-1.95)^{*}$ & $(-5.13)^{* * *}$ & $(3.78)^{* * *}$ & & & \\
\hline \multirow[t]{2}{*}{1994} & -0.786 & 0.369 & 0.231 & .0067 & -0.920 & -0.150 & 0.041 & 0.707 & 0.665 & -0.041 \\
\hline & -1.312 & $(6.357)^{* * *}$ & 1.228 & 0.555 & $(-1.89)^{*}$ & $(-2.72)^{* * *}$ & 1.579 & & & \\
\hline \multirow[t]{2}{*}{1995} & -1.096 & 0.429 & 1.359 & -0.035 & -1.048 & -0.151 & -0.002 & 0.725 & 0.710 & -0.014 \\
\hline & $(-1.644)^{*}$ & -6.904 & $(3.240)^{* * *}$ & -1.144 & $(-2.08)^{* *}$ & $(-2.57)^{*}$ & -0.074 & & & \\
\hline \multirow[t]{2}{*}{1996} & -1.533 & 0.338 & 0.618 & 0.034 & -0.642 & -0.091 & 0.027 & 0.755 & 0.734 & -0.020 \\
\hline & $(-2.278)^{* *}$ & -5.757 & 1.506 & 1.001 & -1.332 & -1.456 & 1.149 & & & \\
\hline \multirow[t]{2}{*}{1997} & -2.319 & 0.376 & 0.366 & 0.072 & 0.125 & -0.124 & 0.036 & 0.771 & 0.749 & -0.021 \\
\hline & $(-3.328)^{* * *}$ & $(6.246)^{* * *}$ & 0.966 & $(2.065)^{* *}$ & 0.260 & $(-1.92)^{*}$ & $(1.89)^{*}$ & & & \\
\hline \multirow[t]{2}{*}{1998} & -2.058 & 0.408 & -0.393 & 0.083 & 0.318 & -0.111 & 0.045 & 0.761 & 0.770 & 0.009 \\
\hline & $(-3.193)^{* * *}$ & $(6.670)^{* * *}$ & -1.623 & $(3.361)^{* * *}$ & 0.631 & $(-1.86)^{*}$ & 1.423 & & & \\
\hline \multirow[t]{2}{*}{1999} & -2.228 & 0.386 & -0.592 & 0.123 & -0.323 & -0.051 & 0.024 & 0.781 & 0.760 & -0.021 \\
\hline & $(-3.400)^{* * *}$ & $(6.605)^{* * *}$ & $(-2.354)^{* *}$ & $(4.726)^{* * *}$ & -0.653 & -0.819 & 0.829 & & & \\
\hline \multirow[t]{2}{*}{2000} & -2.040 & 0.404 & 0.071 & 0.047 & 0.105 & -0.063 & 0.012 & 0.774 & 0.784 & 0.011 \\
\hline & $(-3.093)^{* * *}$ & $(6.652)^{* * *}$ & 0.424 & $(2.719) * * *$ & 0.209 & -1.570 & 0.717 & & & \\
\hline
\end{tabular}


Table 4. Logit Regression for banks kept paying dividend every year to follow the trend of dividends paying propensity for each year $t$ for the banks kept paying for the whole period for the period 1993-2000

\begin{tabular}{llllllll}
\hline & C & LOGTA & ROA & ROE & LOAN_TA & EQUITYTA & EQUITYLI \\
\hline $1993-2000$ & -0.740 & 0.237 & 0.359 & 0.104 & -0.190 & -0.044 & 0.005 \\
& $(-2.01)^{* *}$ & $(7.35)^{* * *}$ & 1.603 & $(5.39)^{* * *}$ & -0.618 & $(-1.76)^{*}$ & 0.880 \\
1993 & -2.128 & 0.298 & 1.223 & 0.049 & -0.617 & 0.286 & -0.242 \\
& -1.475 & $(3.31)^{* * *}$ & 1.183 & 0.624 & -0.705 & 0.863 & -1.164 \\
1994 & -1.997 & 0.331 & -0.686 & 0.207 & -1.566 & 0.182 & -0.043 \\
& -1.446 & $(2.99)^{* * *}$ & -0.635 & $(2.41)^{* *}$ & -1.507 & 1.318 & -1.087 \\
1995 & 1.364 & 0.252 & 0.469 & 0.059 & -2.192 & -0.098 & 0.009 \\
& 1.201 & $(2.54)^{* *}$ & 0.670 & 1.039 & $(-2.25)^{* *}$ & -1.180 & 0.198 \\
1996 & -1.109 & 0.173 & 3.078 & -0.048 & 1.951 & -0.213 & 0.050 \\
& -0.888 & $(1.69)^{*}$ & $(3.08)^{* * *}$ & -0.610 & $(2.31)^{* * *}$ & $(-1.87)^{* *}$ & 1.384 \\
1997 & 0.202 & 0.144 & -0.297 & 0.129 & 0.257 & -0.041 & 0.009 \\
& 0.161 & 1.463 & -0.354 & $(1.80)^{* *}$ & 0.286 & -0.335 & 0.291 \\
1998 & -0.991 & 0.230 & -1.543 & 0.265 & -0.995 & 0.057 & 0.002 \\
& -0.873 & $(2.48)^{* * *}$ & $(-2.82)^{* * *}$ & $(4.79)^{* * *}$ & -1.107 & 0.628 & 0.073 \\
& -2.754 & 0.300 & -0.246 & 0.158 & 0.063 & 0.460 & -0.304 \\
& $\left(-(2.25)^{* *}\right.$ & $(3.07)^{* * *}$ & -0.476 & $(3.28)^{* * *}$ & 0.071 & $(1.90)^{*}$ & $(-1.89)^{*}$
\end{tabular}

The dependent variable is 1 in year $\mathrm{t}$ if the bank pays dividends, 0 otherwise. The explanatory variables are Log of Total Assets (LOGTA), Return on Assets (ROA), Return on Equity (ROE), Loan to Total Assets (LOAN_TA), Equity to Total Assets (EQUITYTA), and Equity to Total Liabilities (EQUITYLI). This table shows the means (across years) of the regression intercept (C) and slopes, and the significant $t$ statistics for the means are given in parentheses. Using the same explanatory variables, we also used 1993 as a base period to estimate logit regressions that explain whether a bank pays dividends. Starting out expectations from 1993 logit (Expected) we compare it with the Actual numbers of 1994, and so on. 
Table 5. Logit Regression for the banks kept paying every year to follow the trend of dividends paying propensity for each lagged year $\mathrm{t}-1$, for the period 1993-2000

\begin{tabular}{|c|c|c|c|c|c|c|c|c|c|c|}
\hline & $\mathrm{C}$ & LOGTA & ROA & ROE & LOAN_TA & EQUITYTA & EQUITYLI & ACTUA & EXPECTED & EX-AC \\
\hline \multirow[t]{2}{*}{$94-2000$} & -0.155 & 0.263 & -0.180 & 0.071 & -0.273 & -0.027 & $7.74 \mathrm{E}-03$ & & & \\
\hline & -0.397 & $(7.68)^{* * *}$ & -1.271 & $(5.15)^{* * *}$ & -0.829 & -0.989 & 0.778 & & & \\
\hline \multirow[t]{2}{*}{1994} & 2.554 & 0.191 & 4.488 & -0.234 & -0.705 & -0.468 & 0.037 & 0.929 & 0.843 & -0.086 \\
\hline & $(2.23)^{* *}$ & $(2.26)^{* *}$ & $(4.29)^{* * *}$ & $(-3.22)^{* * *}$ & -0.872 & $(-3.40)^{* * *}$ & 0.798 & & & \\
\hline \multirow[t]{2}{*}{1995} & -0.140 & 0.362 & 0.941 & 0.022 & -1.934 & $6.27 \mathrm{E}-03$ & -0.037 & 0.913 & 0.907 & -0.006 \\
\hline & -0.114 & $(3.39)^{* * *}$ & 1.145 & 0.352 & $(-1.91)^{*}$ & 0.075 & -0.990 & & & \\
\hline \multirow[t]{2}{*}{1996} & -0.141 & 0.258 & 0.136 & 0.023 & -0.570 & $2.17 \mathrm{E}-01$ & -0.157 & 0.933 & 0.905 & -0.027 \\
\hline & -0.104 & $(2.65)^{* * *}$ & 0.184 & 0.367 & -0.626 & 0.960 & -1.264 & & & \\
\hline \multirow[t]{2}{*}{1997} & -1.172 & 0.202 & 0.423 & 0.071 & 1.399 & $-5.56 \mathrm{E}-02$ & 0.023 & 0.927 & 0.918 & -0.008 \\
\hline & -0.940 & $(2.08)^{* *}$ & 0.454 & 0.953 & $(1.668)^{*}$ & -0.394 & 0.544 & & & \\
\hline \multirow[t]{2}{*}{1998} & 0.875 & 0.194 & -0.679 & 0.082 & 0.308 & $-8.28 \mathrm{E}-02$ & 0.043 & 0.916 & 0.927 & 0.011 \\
\hline & 0.729 & $(1.96)^{* *}$ & $(-2.07)^{* *}$ & $(2.17)^{* *}$ & 0.318 & -0.490 & 0.415 & & & \\
\hline \multirow[t]{2}{*}{1999} & -2.638 & 0.299 & -0.762 & 0.135 & -2.051 & $1.98 \mathrm{E}+00$ & -1.482 & 0.925 & 0.902 & -0.023 \\
\hline & $(-2.04)^{* *}$ & $(3.27)^{* * *}$ & $(-2.40)^{* *}$ & $(3.74)^{* * *}$ & $(-2.19)^{* *}$ & $(3.29)^{* * *}$ & $(-3.18)^{* * *}$ & & & \\
\hline \multirow[t]{2}{*}{2000} & -1.452 & 0.328 & -0.361 & 0.087 & -0.043 & $3.29 \mathrm{E}-01$ & -0.234 & 0.891 & 0.912 & 0.021 \\
\hline & -1.159 & $(3.49)^{* * *}$ & -1.336 & $(3.088)^{* * *}$ & -0.049 & 0.943 & -0.946 & & & \\
\hline
\end{tabular}

Table 6. Logit Regression for banks stopped paying dividend to follow the trend of dividends paying propensity for each year $\mathrm{t}$ for the banks kept paying for the whole period, for the period 1993-2000

\begin{tabular}{cccccccc}
\hline PERIOD & C & LOGTA & ROA & ROE & LOAN_TA & EQUITYTA & EQUITYLI \\
\hline \multirow{2}{*}{$1993-2000$} & 0.554 & -0.201 & -0.316 & 0.130 & -3.155 & 1.737 & -1.366 \\
& 0.284 & -1.612 & -0.968 & $(2.58)^{* * *}$ & $(-3.07)^{* * *}$ & $(1.74)^{*}$ & $(-1.78)^{*}$ \\
1993 & -23.591 & 1.119 & -11.143 & 1.214 & 1.174 & 1.297 & 0.203 \\
& -0.739 & 1.023 & -0.711 & 0.820 & 0.094 & 0.678 & 0.222 \\
1994 & 0.018 & -0.019 & -0.017 & 0.017 & 0.008 & -0.016 & 0.016 \\
& 2119.490 & 14.224 & 591.473 & -44.452 & 490.626 & -3330.370 & 2762.8 \\
1995 & -1.910 & 58.492 & -130.335 & 27.829 & 375.059 & 285.28 & -209.6 \\
\multirow{2}{*}{1996} & -0.009 & 0.008 & -0.003 & 0.006 & 0.008 & 0.011 & -0.010 \\
& 43.506 & -3.379 & -17.892 & 5.401 & -163.949 & 89.472 & -72.554 \\
1997 & 0.000 & 0.000 & 0.000 & 0.001 & -0.003 & 0.001 & -0.001 \\
& -36.840 & -0.304 & -59.301 & 5.125 & -10.960 & 1.019 & 3.946 \\
\multirow{2}{*}{1998} & -0.801 & -0.468 & -0.992 & 1.018 & -1.356 & 0.096 & 0.517 \\
& 1.988 & -0.130 & 0.502 & 0.000 & -0.521 & 0.775 & -0.919 \\
& 0.254 & -0.285 & 0.098 & 0.000 & -0.167 & 0.142 & -0.204 \\
& -514.141 & -82.774 & 77.627 & -8.761 & 1625.2 & -55.710 & 23.740 \\
& -0.015 & -0.011 & 0.007 & -0.008 & 0.013 & -0.001 & 0.001 \\
& -4227.450 & 10.607 & -464.401 & 36.248 & -68.369 & 8196.480 & -7070.4
\end{tabular}

The dependent variable is 1 in year $t$ if the bank pays dividends, 0 otherwise. The explanatory variables are Log of Total Assets (LOGTA), Return on Assets (ROA), Return on Equity (ROE), Loan to Total Assets (LOAN_TA), Equity to Total Assets (EQUITYTA), and Equity to Total Liabilities (EQUITYLI). This table shows the means (across years) of the reg ression intercept (C) and slopes, and the significant tstatistics for the means are given in parentheses. Using the same explanatory variables, we also used 1993 as a base period to estimate logit regressions that explain whether a bank pays dividends. Starting out expectations from 1993 logit (Expected) we compare it with the Actual numbers of 1994, and so on. 
Table 7. Logit Regression for the banks stopped paying dividends to follow the trend of dividends paying propensity for each lagged year $\mathrm{t}-1$, for the period 1993-2000

\begin{tabular}{|c|c|c|c|c|c|c|c|c|c|c|}
\hline & $\mathrm{C}$ & LOGTA & ROA & ROE & LOAN_TA & EQUITYTA & EQUITYLI & ACTUAL & EXPECTED & EX-AC \\
\hline \multirow[t]{2}{*}{$1994-2000$} & 1.717 & -0.146 & -0.685 & 0.145 & -2.461 & 0.066 & -0.018 & & & \\
\hline & 1.130 & -1.120 & -1.890 & 2.700 & -2.349 & 0.754 & -0.515 & & & \\
\hline \multirow[t]{2}{*}{1994} & 265.815 & 21.000 & 24.604 & -7.631 & 241.396 & -324.831 & 243.602 & 1.000 & 0.714 & -0.286 \\
\hline & 0.000 & 0.001 & 0.001 & -0.001 & 0.001 & 0.000 & 0.000 & & & \\
\hline \multirow[t]{2}{*}{1995} & -1090.990 & 58.492 & -130.335 & 27.829 & 375.059 & 285.288 & -209.693 & 0.935 & 0.825 & -0.110 \\
\hline & -0.009 & 0.008 & -0.003 & 0.006 & 0.008 & 0.011 & -0.010 & & & \\
\hline \multirow[t]{2}{*}{1996} & -454.828 & 5.465 & 6.225 & 10.035 & -16.604 & 319.629 & -250.014 & 0.882 & 0.824 & -0.059 \\
\hline & -0.005 & 0.001 & 0.000 & 0.002 & -0.001 & 0.004 & -0.004 & & & \\
\hline \multirow[t]{2}{*}{1997} & -27.645 & 15.300 & 135.000 & -8.470 & -151.000 & 62.400 & -51.200 & 0.588 & 0.882 & 0.294 \\
\hline & 0.000 & 0.000 & 0.000 & 0.000 & 0.000 & 0.000 & 0.000 & & & \\
\hline \multirow[t]{2}{*}{1998} & -3.430 & 0.243 & -1.050 & 0.146 & -4.290 & 3.530 & -2.675 & 0.263 & 0.632 & 0.368 \\
\hline & -0.511 & 0.488 & -0.413 & 0.779 & -1.099 & 1.213 & -1.218 & & & \\
\hline \multirow[t]{2}{*}{1999} & -5.140 & 0.433 & -3.640 & 0.312 & 1.010 & -0.307 & 0.281 & 0.043 & 0.348 & 0.304 \\
\hline & -1.009 & 0.967 & -0.922 & 0.995 & 0.350 & -0.327 & 0.445 & & & \\
\hline \multirow[t]{2}{*}{2000} & -727.000 & -25.000 & 287.000 & -19.000 & 47.200 & 2160.000 & -1895.860 & 0.083 & 0.042 & -0.042 \\
\hline & -0.001 & -0.001 & 0.000 & -0.001 & 0.000 & 0.012 & -0.017 & & & \\
\hline
\end{tabular}

The dependent variable is 1 in year $t$ if the bank pays dividends, 0 otherwise. The explanatory variables are Log of Total Assets (LOGTA), Return on Assets (ROA), Return on Equity (ROE), Loan to Total Assets (LOAN_TA), Equity to Total Assets (EQUITYTA), and Equity to Total Liabilities (EQUITYLI). This table shows the means (across years) of the regression intercept (C) and slopes, and the significant $t$ statistics for the means are given in parentheses. Using the same explanatory variables, we also used 1993 as a base period to estimate logit regressions that explain whether a bank pays dividends. Starting out expectations from 1993 logit (Expected) we compare it with the Actual numbers of 1994, and so on.

Table 8. Logit Regression for banks paid more than $100 \%$ of their net income to follow the trend of dividends paying propensity for each year $t$ for the banks kept paying for the whole period, for the period 1993-2000

\begin{tabular}{cccccccc}
\hline PERIOD & C & LOGTA & ROA & ROE & LOAN_TA & EQUITYTA & EQUITYLI \\
\hline \multirow{2}{*}{$1993-2000$} & -0.499 & 0.001 & 0.011 & 0.067 & 2.350 & 0.259 & -0.250 \\
& -0.105 & 0.007 & 0.011 & 0.821 & 0.551 & 0.116 & -0.142 \\
\multirow{2}{*}{1993} & 1288.300 & -95.700 & -600.000 & 55.400 & 367.000 & -2180.000 & 1943.150 \\
& 0.018 & -0.019 & -0.017 & 0.017 & 0.008 & -0.016 & 0.016 \\
1994 & 2119.490 & 14.224 & 591.473 & -44.452 & 490.626 & -3330.370 & 2762.870 \\
& 0.023 & 0.020 & 0.025 & -0.025 & 0.016 & -0.024 & 0.024 \\
1995 & -12.357 & -0.103 & 1.493 & -0.195 & 12.581 & 14.588 & -12.533 \\
& -0.749 & -0.231 & 0.414 & -0.620 & 0.959 & 1.313 & -1.384 \\
1996 & 32.097 & -0.251 & 5.542 & -0.541 & 18.195 & -36.893 & 29.279 \\
& 1.124 & -0.320 & 0.740 & -0.824 & 1.466 & $-1.68)^{* *}$ & $(1.68)^{* *}$ \\
1997 & -1914.970 & -1.100 & -234.796 & 22.880 & 852.439 & 1006.800 & -788.587 \\
& -0.010 & 0.000 & -0.014 & 0.013 & 0.007 & 0.013 & -0.012 \\
\multirow{2}{*}{1998} & 213.490 & 14.224 & 591.473 & -44.452 & 490.626 & -3330.370 & 2762.870 \\
& 0.022 & 0.030 & 0.025 & -0.025 & 0.016 & -0.024 & 0.024 \\
& 2119.490 & $9 . .2237$ & 421.473 & -42.452 & 511.626 & -2812.370 & 3062.250 \\
& 0.023 & 0.020 & 0.028 & -0.015 & 0.022 & -0.044 & 0.033 \\
& 16.501 & 0.204 & 4.048 & -0.111 & -16.410 & -4.955 & 3.836 \\
& 0.787 & 0.483 & 1.336 & -0.512 & -0.904 & -0.746 & 0.735 \\
\hline
\end{tabular}


Table 9. Logit Regression for banks paid more than $100 \%$ of their net income to follow the trend of dividends paying propensity for each lagged year $\mathrm{t}-1$, for the period 1993-2000

\begin{tabular}{|c|c|c|c|c|c|c|c|c|c|c|}
\hline PERIOD & $\mathrm{C}$ & LOGTA & ROA & ROE & LOAN_TA & EQUITYTA & EQUITYLI & ACTUAL & EXPECTED & EX-AC \\
\hline \multirow[t]{2}{*}{ 1994-200 } & -0.699 & 0.004 & -0.489 & 0.057 & 5.731 & -1.120 & 0.840 & & & \\
\hline & -0.131 & 0.024 & -0.502 & 0.576 & 1.284 & -0.436 & 0.415 & & & \\
\hline \multirow[t]{2}{*}{1994} & 3417.730 & -21.042 & -192.643 & 20.946 & 1137.360 & -7956.200 & 6837.760 & 0.939 & 0.879 & -0.061 \\
\hline & 0.029 & -0.010 & -0.004 & 0.005 & 0.024 & -0.030 & 0.030 & & & \\
\hline \multirow[t]{2}{*}{1995} & 6.330 & 0.314 & 8.610 & -1.018 & 56.300 & -25.600 & 19.012 & 0.778 & 0.889 & 0.111 \\
\hline & 0.338 & 0.404 & 1.042 & -1.201 & 1.298 & -0.960 & 0.931 & & & \\
\hline \multirow[t]{2}{*}{1996} & -5.845 & 0.092 & -0.998 & 0.070 & 7.785 & 2.775 & -2.452 & 0.892 & 0.784 & -0.108 \\
\hline & -0.439 & 0.271 & -0.220 & 0.177 & 0.749 & 0.389 & -0.447 & & & \\
\hline \multirow[t]{2}{*}{1997} & 31.266 & -1.323 & -2.991 & 0.525 & 8.233 & -30.582 & 25.118 & 0.976 & 0.905 & -0.071 \\
\hline & 0.827 & -0.962 & -0.305 & 0.619 & 0.535 & -0.992 & 0.988 & & & \\
\hline \multirow[t]{2}{*}{1998} & 462.327 & -16.463 & 76.828 & -11.850 & -152.934 & 255.341 & -226.152 & 0.953 & 0.977 & 0.023 \\
\hline & 0.002 & -0.004 & 0.002 & -0.004 & -0.001 & 0.001 & -0.002 & & & \\
\hline \multirow[t]{2}{*}{1999} & -23.835 & 2.003 & -97.412 & 10.574 & -287.829 & 141.538 & -102.891 & 0.977 & 0.953 & -0.023 \\
\hline & 0.000 & 0.000 & -0.004 & 0.004 & 0.000 & 0.001 & 0.000 & & & \\
\hline \multirow[t]{2}{*}{2000} & -465.902 & -32.567 & -254.049 & 22.121 & 367.912 & 503.154 & -386.446 & 0.860 & 0.977 & 0.116 \\
\hline & -0.001 & -0.009 & -0.005 & 0.004 & 0.001 & 0.002 & -0.002 & & & \\
\hline
\end{tabular}

Table 10. Logit Regression for banks started paying dividends to follow the trend of dividends paying propensity for each year $t$ for the banks kept paying for the whole period, for the period 1993-2000

\begin{tabular}{cccccccc}
\hline PERIOD & C & LOGTA & ROA & ROE & LOAN_TA & EQUITYTA & EQUITYLI \\
\hline \multirow{2}{*}{$1993-2000$} & -3.112 & 0.313 & 0.091 & 0.041 & 0.821 & -0.078 & 0.038 \\
& $(-4.61)^{* * *}$ & $(4.81)^{* * *}$ & 0.432 & $(2.19)^{* *}$ & 1.646 & -1.233 & 0.913 \\
1993 & -31.936 & 0.387 & 8.288 & -0.325 & -9.024 & 97.196 & -86.890 \\
& -0.359 & 0.626 & 0.472 & -0.352 & -0.997 & 0.397 & -0.402 \\
1994 & -75.034 & 0.650 & 0.746 & -0.068 & 2.517 & 87.407 & -72.803 \\
& -1.284 & 0.909 & 0.663 & -0.852 & 0.423 & 1.090 & -1.084 \\
1995 & -3.256 & 0.178 & -1.025 & 0.118 & -0.186 & -0.309 & 0.326 \\
& -1.120 & 0.845 & -0.818 & 1.130 & -0.109 & -0.306 & 0.450 \\
1996 & -0.476 & -0.093 & -0.773 & 0.118 & 0.258 & 0.106 & -0.113 \\
& -0.208 & -0.498 & -0.676 & 1.235 & 0.174 & 0.171 & -0.257 \\
1997 & -0.754 & 0.082 & 1.587 & -0.051 & 0.913 & 0.892 & -0.943 \\
& -0.236 & 0.452 & 1.203 & -0.457 & 0.628 & 0.427 & -0.569 \\
\multirow{2}{*}{1998} & -0.771 & 0.134 & -0.973 & 0.190 & 0.006 & -0.199 & 0.124 \\
& -0.385 & 0.714 & -1.398 & $(2.29)^{* *}$ & 0.004 & -1.095 & 1.003 \\
& 0.083 & 0.319 & -0.958 & 0.163 & -0.244 & -0.573 & 0.386 \\
& 0.031 & 1.251 & -0.706 & 1.320 & -0.128 & -1.219 & 1.229 \\
& 9.773 & -0.534 & 14.356 & -0.643 & 6.032 & -8.020 & 6.096 \\
\end{tabular}

The dependent variable is 1 in year $t$ if the bank pays dividends, 0 otherwise. The explanatory variables are Log of Total Assets (LOGTA), Return on Assets (ROA), Return on Equity (ROE), Loan to Total Assets (LOAN_TA), Equity to Total Assets (EQUITYTA), and Equity to Total Liabilities (EQUITYLI). This table shows the means (across years) of the regression intercept (C) and slopes, and the significant $t-$ statistics for the means are given in parentheses. Using the same explanatory variables, we also used 1993 as a base period to estimate logit regressions that explain whether a bank pays dividends. Starting out expectations from 1993 logit (Expected) we compare it with the Actual numbers of 1994 , and so on. (***, **,*, are significance levels at $1 \%, 5 \%$, and $10 \%$ respectively) 
Table 11. Logit Regression for banks started paying dividends to follow the trend of dividends paying propensity for each lagged year $\mathrm{t}-1$, for the period 1993-2000

\begin{tabular}{|c|c|c|c|c|c|c|c|c|c|c|}
\hline PERIOD & $\mathrm{C} 1$ & LOGTA & ROA & ROE & LOAN_TA & EQUITYTA & EQUITYLI & ACTUAL & EXPECTED & EX-AC \\
\hline \multirow[t]{2}{*}{ 1994-200 } & $(-2.48)^{* * *}$ & $(.27)^{* * *}$ & $(-6.33)^{* * *}$ & $(.073)^{* * *}$ & 0.625 & $(-.209)^{* * *}$ & $(.141)^{* * *}$ & & & \\
\hline & 213.873 & 12.616 & 38.434 & 2.543 & -165.762 & -266.740 & 198.033 & 0.026 & 0.013 & -0.013 \\
\hline \multirow[t]{2}{*}{1994} & 0.010 & 0.017 & 0.003 & 0.002 & -0.014 & -0.016 & 0.016 & & & \\
\hline & -62.245 & 0.771 & 19.282 & -1.178 & 7.718 & 84.887 & -73.194 & 0.227 & 0.023 & -0.205 \\
\hline \multirow[t]{2}{*}{1995} & -1.179 & 0.680 & 1.245 & -1.218 & 0.627 & 1.111 & -1.113 & & & \\
\hline & -4.116 & 0.116 & -0.056 & 0.014 & 0.219 & 1.800 & -1.454 & 0.365 & 0.198 & -0.167 \\
\hline \multirow[t]{2}{*}{1996} & -1.320 & 0.553 & -0.050 & 0.170 & 0.124 & 0.770 & -0.772 & & & \\
\hline & -2.437 & -0.031 & -0.318 & 0.078 & 0.773 & 2.021 & -1.729 & 0.529 & 0.353 & -0.176 \\
\hline \multirow[t]{2}{*}{1997} & -0.698 & -0.168 & -0.234 & 0.682 & 0.491 & 0.841 & -0.901 & & & \\
\hline & -1.532 & 0.188 & -0.952 & 0.125 & 2.222 & -0.432 & 0.243 & 0.645 & 0.514 & -0.131 \\
\hline \multirow[t]{2}{*}{1998} & -0.763 & 1.013 & -1.400 & $(1.88)^{* *}$ & 1.429 & $(-2.44)^{* *}$ & $(2.03)^{* *}$ & & & \\
\hline & -0.013 & 0.209 & -1.914 & 0.180 & 0.092 & -0.490 & 0.345 & 0.833 & 0.639 & -0.194 \\
\hline \multirow[t]{2}{*}{1999} & -0.007 & 1.058 & $(-2.58)^{* *}$ & $(2.35)^{* *}$ & 0.059 & $(-2.34)^{* *}$ & $(2.36)^{* *}$ & & & \\
\hline & -1.364 & 0.446 & -3.299 & 0.281 & 0.284 & -1.043 & 0.918 & 0.907 & 0.832 & -0.075 \\
\hline \multirow[t]{2}{*}{2000} & -0.500 & $(1.698)^{* *}$ & $(-2.62)^{* * *}$ & $(2.70)^{* * *}$ & 0.144 & $(-2.21)^{* * *}$ & $(2.49)^{* *}$ & & & \\
\hline & $(-2.48)^{* * *}$ & $(.27)^{* * *}$ & $(-6.33) * * *$ & $(.073)^{* * *}$ & 0.625 & $(-.209) * * *$ & $(.141)^{* * *}$ & & & \\
\hline
\end{tabular}

The dependent variable is 1 in year $t$ if the bank pays dividends, 0 otherwise.The explanatory variables are Log of Total Assets (LOGTA), Return on Assets (ROA), Return on Equity (ROE), Loan to Total Assets (LOAN_TA), Equity to Total Assets (EQUITYTA), and Equity to Total Liabilities (EQUITYLI). This table shows the means (across years) of the regression intercept (C) and slopes, and the significant $t-$ statistics for the means are given in parentheses. Using the same explanatory variables, we also used 1993 as a base period to estimate logit regressions that explain whether a bank pays dividends. Starting out expectations from 1993 logit (Expected) we compare it with the Actual numbers of 1994, and so on.

\section{Conclusions}

This paper employed Fama and French's (2001) logit model to explore an idea about the dividend-paying propensity adopted by U.S. banks and to explain dividend pay-out ratios in the U.S. banking sector. Our findings show that banks, in general, kept paying dividends at increasing rates. The findings also show that the main factors affecting dividend-paying in banks are the total assets, return on equity, and equity to liability ratio. The first two variables affect the dividend pay-out positively, and the third affects it negatively. For comparative reasons, we break down our sample into subsets according to their recent dividend-paying characteristics to account for the changes of the regression parameters for each group (never stopped paying, never paid, stopped paying, and started paying). The only group that shows real significant coefficients for all variables is the "started paying" group.

\section{References}

Acharya, V., Gujral, I., \& Shin, H.S. (2011). Dividends and Bank Capital in the Financial Crisis of 2007-2009. National Bureau of Economic Research. Working Paper Number 16896. http://dx.doi.org/10.3386/w16896

Akhigbe, A., Borde, S. F., \& Madura, J. (1993). Dividend Policy and Signaling by Insurance Companies. The Journal of Risk and Insurance, 60(3), 413-428.

Akhigbe, A., \& Whyte, A. M. (2012). Does the use of stock incentives influence the payout policy of financial institutions? The Quarterly Review of Economics and Finance, 52(1), 63-71. http://dx.doi.org/10.1016/j.qref.2011.12.003

Alli, K. L., Khan, A. Q., \& Ramirez, G. G. (1993). Determinants of corporate dividend policy: a factorial analysis. The Financial Review, 28(4), 523-547.

Baker, H.K., Dutta, S., \& Saadi, S. (2008). Impact of Financial and Multinational Operations on Manager Perceptions of Dividends. Global Finance Journal, 19(2), 171-186. http://dx.doi.org/10.1016/j.gfj.2007.11.002

Baker, H. K., Veit, E. T., \& Powell, G. E. (2001). Factors Influencing Dividend Policy Precisions of NASDAQ Firms. Financial Review, 36(3), 19-38. http://dx.doi.org/10.1111/j.1540-6288.2001.tb00018.x 
Barclay, M. J., Smith, C. W. Jr., \& Watts, R. L. (1995). The Determinants of Corporate Leverage and Dividend $\begin{array}{lllll}\text { Policies. Journal of Applied Corporate Finance, 7(4), 214-229. } & \text {. }\end{array}$ http://dx.doi.org/10.1111/j.1745-6622.1995.tb00259.x

Bessler, W., \& Nohel, T. (1996). The Stock-Market Reaction to Dividend Cuts and Omissions by Commercial Banks. Journal of Banking and Finance, 20(9), 1485-1508. http://dx.doi.org/10.1016/S0378-4266(96)00004-0

Bessler, W., \& Nohel, T. (2000). Asymmetric Information, Dividend Reductions, and Contagion Effect in Bank Stock Returns. Journal of Banking and Finance, 24(11), 1831-1848. http://dx.doi.org/10.1016/S0378-4266(99)00097-7

Bodla, B. S., Pal, K., \& Sura, J. S. (2007). Examining Application of Lintner's Dividend Model in Indian Banking Industry. The IUP Journal of Bank Management, 6(4), 40-59.

Boldin, R., \& Leggett, K. (1995). Bank Dividend Policy as a Signal of Bank Quality. Financial Services Review, 4(1), 1-8. http://dx.doi.org/10.1016/1057-0810(95)90013-6

Brennan, M. J., \& Thakor, A. V. (1990). Shareholder Preferences and Dividend Policy. Journal of Finance, 45(4), 993-1019.

Caprio, G., Laeven, L., \& Levine, R. (2007). Governance and Banks Valuations. Journal of Financial Intermediation, 16(4), 584-617. http://dx.doi.org/10.1016/j.jfi.2006.10.003

Dickens, R. N., Casey, K. M., \& Newman, J. A (2002). Bank Dividend Policy: Explanatory Factors. Quarterly Journal of Business and Economics, 41(1), 3-12.

Collins, M. C., Saxena, A. K., \& Wansley, J. W. (1996). The Role of Insiders and Dividend Policy: A Comparison of Regulated and Unregulated Firms. Journal of Financial and Strategic Decisions, 9(2), 1-9.

DeAngelo, H., DeAngelo, L., \& Skinner, D. J. (2000). Special Dividends and the Evolution of Dividend $\begin{array}{lllll}\text { Signaling. Journal of } & \text { Financial }\end{array}$ http://dx.doi.org/10.1016/S0304-405X(00)00060-X

DeAngelo, H., DeAngelo, L., \& Skinner, D. J. (2004). Are dividends disappearing? Dividend concentration and the consolidation of earnings. Journal of Financial Economics, 72(3), 425-456. http://dx.doi.org/10.1016/S0304-405X(03)00186-7

De Jong, A., Van Dijk, R., \& Veld, C. (2003). The Dividend and Share Repurchase Policies of Canadian Firms: Empirical Evidence Based on an Alternative Research Design. International Review of Financial Analysis, 12(4), 349-377. http://dx.doi.org/10.1016/S1057-5219(03)00030-9

Dempsey, S. J., Laber, G., \& Rozeff, M. S. (1993). Dividend Policies in Practice: Is There an Industry Effect? Quarterly Journal of Business and Economics, 32(4), 3-13.

Cornett, M. M., Fayman, A., Marcus, A. J., \& Tehranian, H. (2011). Dividends, maturity, and acquisitions: Evidence from a sample of bank IPOs. Review of Financial Economics, 20(2), 11-21. http://dx.doi.org/10.1016/j.rfe.2010.11.001

Fama, E. F., \& French, K. R. (2001). Disappearing Dividends: Changing Firm Characteristics or Lower Propensity to Pay? Journal of Financial Economics, 60(1), 3-43. http://dx.doi.org/10.1016/S0304-405X(01)00038-1

Fenn, G. W., \& Liang, N. (2001). Corporate Payout Policy and Managerial Stock Incentives. Journal of Financial Economics, 60(1), 45-72. http://dx.doi.org/10.1016/S0304-405X(01)00039-3

Frankfurter, G. M., Wood, G. B., \& Wansley, J. W. (2003). Dividend Policy: Theory and Practice. San Diego, CA: Academic Press.

Grullon, G., \& Michaely, R. (2002). Dividends, Share Repurchases, and the Substitution Hypothesis. Journal of Finance, 57(4), 1649-1684. http://dx.doi.org/10.1111/1540-6261.00474

Lintner, J. (1956). Distribution of Incomes of Corporations Among Dividends, Retained Earnings and Taxes. American Economics Review, 46(2), 97-113.

Miller, M. H., \& Modigliani, F. (1961). Dividend Policy, Growth, and the Valuation of Shares. Journal of Business, 34(4), 411-433. http://dx.doi.org/10.1086/294442

Miller, M. H., \& Rock, K. (1985). Dividend Policy under Asymmetric Information. Journal of Finance, 40(4), 1031-1051. 
Moyer, R. C., Rao, R., \& Tripathy, N. (1992). Dividend Policy and Regulatory Risk: A Test of the Smith Hypothesis. Journal of Economics and Business, $44(2), \quad 127-134$. http://dx.doi.org/10.1016/0148-6195(92)90011-X

Moyer, R. C., Chatfield, R. E., \& Sisneros, P. M. (1989). Security Analyst Monitoring Activity: Agency Costs and Information Demands. Journal of Financial and Quantitative Analysis, 24(4), 503-512. http://dx.doi.org/10.2307/2330982

Akpomi, M., \& Nnadi, M. (2008). The Effect of Taxes on Dividend Policy of Banks in Nigeria. International Research Journal of Finance and Economics, 19(7), 48-55.

Onali, E. (2012). Moral Hazard, Dividends and Risk in Banks. Bangor Business School Research Paper No 11/012. http://papers.ssrn.com/sol3/papers.cfm?abstract_id=1980130

Raghavan, K. (2005). Share Repurchases as Signals in Banking: Do they work? SSRN:http://ssrn.com/abstract $=772404$

Rozeff, M. S. (1982). Growth, Beta and Agency Costs as Determinants of Dividend Payout Ratios. Journal of Financial Research, 5(3), 249- 259.

Slovin, M. B., Sushka, M. E., \& Polonchek, J. A. (1999). An Analysis of Contagion and Competitive Effects at Commercial Banks. Journal of Financial Economics, 54(2), $197-225$. http://dx.doi.org/10.1016/S0304-405X(99)00036-7

Smith, C. W. (1986). Investment Banking and the Capital Acquisition Process. Journal of Financial Economics, 15(1-2), 3-29. http://dx.doi.org/10.1016/0304-405X(86)90048-6 